\title{
Pathological findings in fetuses of goats and cattle poisoned by Sida carpinifolia (Malvaceae) ${ }^{1}$
}

\author{
Pedro M.O. Pedroso ${ }^{2}$, Edson Moleta Colodel ${ }^{3}$, Anderson Luiz Seitz ${ }^{2}$, Gabriel L.F. \\ Correa $^{2}$, Mauro Pereira Soares ${ }^{4}$ e David Driemeier ${ }^{2 *}$
}

\begin{abstract}
Pedroso P.M.O., Colodel E.M., Seitz A.L., Correa G.L.F., Soares M.P. \& Driemeier D. 2012. Pathological findings in fetuses of goats and cattle poisoned by Sida carpinifolia (Malvaceae). Pesquisa Veterinária Brasileira 32(3):227-230. Setor de Patologia Veterinária, Faculdade de Veterinária, Universidade Federal do Rio Grande do Sul, Av. Bento Gonçalves 9090, Porto Alegre, RS 91540-000, Brazil. E-mail: davetpat@ufrgs.br

In Brazil, the consumption of Sida carpinifolia by livestock has been associated with neurological diseases linked to lysosomal storage disorders. This paper describes the pathological findings in two caprine fetuses from dams that were experimentally poisoned with S. carpinifolia. The goats were orally dosed with 10 and $13 \mathrm{~g} / \mathrm{kg}$ of a paste of green chopped S. carpinifolia for 30 days and were observed for an additional 15 days period after the last dosage with the plant; thereafter they were euthanized and necropsied. The dams showed only slight clinical signs. The study also includes the findings in one bovine fetus from a naturally $S$. carpinifolia poisoned cow which showed mild incoordination, generalized tremors, staggering, and frequent falls. The cow was euthanized and necropsied. While there were no significant histopathological changes in the goats, in the cow vacuolation of Purkinje neurons of the cerebellum, pancreatic acinar cells, and thyroid follicular cells were observed. The main microscopic changes observed in the caprine and bovine fetuses were vacuolation in the epithelium of renal tubules, thyroid follicular cells, and Purkinje neurons of the cerebellum. Transmission electron microscopy of sections from CNS of the cow and its fetus revealed vacuoles containing fine granular material surrounded by membrane. Lectin-histochemistry of CNS sections from goat fetuses marked lightly to sWGA lectins, WGA, and Con-A.
\end{abstract}

INDEX TERMS: Poisonous plants, Swainsonine, Sida carpinifolia, Malvaceae, plant poisoning, lysosomal storage disease, pathological findings, lectin-histochemistry, transmission electron microscopy, caprine and bovine fetuses.

RESUMO.- [Achados patológicos em fetos de caprinos e bovinos intoxicados por Sida carpinifolia (Malvaceae).] No Brasil, o consumo de Sida carpinifolia por animais de produção tem sido associada a doenças neurológicas rela-

\footnotetext{
${ }^{1}$ Received on October 13, 2011.

Accepted for publication on November 18, 2011.

${ }^{2}$ Setor de Patologia Veterinária (SPV), Departamento de Patologia Clínica Veterinária, Faculdade de Veterinária, Universidade Federal do Rio Grande do Sul (UFRGS), Av. Bento Gonçalves 9090, Porto Alegre, RS 95320000, Brazil. *Corresponding author: davetpat@ufrgs.br

${ }^{3}$ Departamento de Clínica Médica Veterinária, Faculdade de Agronomia e Medicina Veterinária, Universidade Federal de Mato Grosso (UFMT), Av. Fernando Correia da Costa s/n, Bairro Coxipó, Cuiabá, MT 78068-900, Brazil.

${ }^{4}$ Laboratório Regional de Diagnóstico, Faculdade de Veterinária, Universidade Federal de Pelotas, Campus Universitário s/n, Pelotas, RS 96010-900, Brazil.
}

cionadas com doença de depósito lisossômico. Este trabalho descreve os achados patológicos observados em dois fetos caprinos de mães que foram experimentalmente intoxicadas por $S$. carpinifolia. As cabras foram intoxicadas experimentalmente com S. carpinifolia nas doses de 10 e $13 \mathrm{~g} / \mathrm{kg}$ durante 30 dias e foram acompanhadas durante 15 dias após o consumo da planta. Após este período foram eutanasiadas e necropsiadas. 0 estudo também inclui os achados patológicos encontrados em um feto de uma fêmea bovina intoxicada naturalmente pela planta, que mostrou leve incoordenação, tremores generalizados, andar desequilibrado e quedas frequentes. A vaca foi eutanasiada e necropsiada. Embora não houvesse alterações histológicas significativas nas cabras, vacuolização dos neurônios de Purkinje do cerebelo, das células acinares do pâncreas e nas células foliculares da tireoide foram observadas na 
vaca. As principais alterações histológicas observadas nos fetos caprinos e no feto bovino foram vacuolização no epitélio dos túbulos renais, nas células foliculares da tireoide e nos neurônios de Purkinje do cerebelo. Na microscopia eletrônica de transmissão do sistema nervoso central da vaca e de seu feto revelaram-se vacúolos contendo material finamente granulado e delimitado por membrana. Na técnica de lectina-histoquímica dos fetos caprinos houve marcação leve no SNC para as lectinas SWGA, WGA e para Con-A.

TERMOS DE INDEXAÇÃO: Plantas tóxicas, Swainsonina, Sida carpinifolia, Malvaceae, doença de depósito lisossomal, achados patológicos, intoxicação por plantas, lectina-histochemica, microscopia eletrônica de transmissão, fetos caprinos e bovinos.

\section{INTRODUCTION}

In Brazil, the consumption by livestock of Sida carpinifolia, also named Sida acuta var. carpinifolia (L.f.) K. Schum. (Malvaceae family), has been associated with lysosomal storage disorders (Driemeier et al. 2000, Colodel et al. 2002a). Although native to tropical America, S. carpinifolia has spread throughout the tropics and subtropics, where it is particularly abundant in humid and reduced sunlight areas (Kismann \& Groth 2000, Lorenzi 2008). The disease is caused by the indolizidine alkaloid swainsonina (Colodel et al. $2002 b$ ) that inhibits the lysosomal enzyme $\alpha$-mannosidase and induces the storage of mannose containing oligosaccharides in lysosomes of several cells, particularly neurons, hepatocytes, and acinar pancreatic cells (Stegelmeier et al. 1995, Jolly \& Walker 1997).

In the first description of the disease in goats (Driemeier et al. 2000), high rates of abortions and stillbirths were reported. The clinical and pathological features seen in herbivores poisoned by $S$. carpinifolia are indistinguishable from those described in livestock poisoned by plants of the genera Swainsona in Australia (Colegate et al. 1979), Astragalus and Oxytropis in the United States (Stegelmeier et al. 1995, Pfister et al. 2003), Ipomoea spp. (Barbosa et al. 2006, Barbosa et al. 2007, Armién et al. 2007, Antoniassi et al. 2007), and Turbina cordata (Dantas et al. 2007) in Brazil. This paper describes the pathologic findings observed in fetuses from livestock poisoned by Sida carpinifolia.

\section{MATERIALS AND METHODS \\ Experimental animals}

Two 2-year-old Saanen goats (Goats 1 and 2), at about six months of pregnancy, were dosed with 10 and $13 \mathrm{~g} / \mathrm{kg}$ of green Sida carpinifolia for 30 days. Animals were observed for an additional period of 15 days after the consumption of the plant. The goats originated from farms free from S. carpinifolia infestation. The plant was chopped and moistened to form a paste, which was orally administered to the goats using an adapted $60 \mathrm{ml}$ syringe. The goats were kept in individual pens, where they also received water ad libitum and $200 \mathrm{~g}$ of commercial concentrate and alfalfa hay.

A for 6-month-pregnant control goat received alfalfa hay, $200 \mathrm{~g}$ of commercial concentrate and water ad libitum. After 15 days of the last dosage, the goats were euthanized and necropsied (Colodel et al. 2002a). The experiment was approved by the Ethic Committee of Universidade Federal do Rio Grande do Sul (UFRGS), and the animal protocol was approved by the Research and Post- graduate Committee of Hospital de Clínicas de Porto Alegre, Brazil (Bedin et al. 2010).

\section{Necropsy and histopathology}

The study also included a 5-month-old bovine fetus, whose dam had been spontaneously poisoned after consumption of $S$. carpinifolia. The cow and the two goats were necropsied, and fragments of organs were collected and fixed in 10\% formalin, processed routinely for histology and stained with hematoxylin and eosin. The same procedures were conducted with the caprine fetuses (Fetus 1 and 2) and the bovine fetus (Fetus 3) and their controls respectively.

\section{Transmission electron microscopy}

Fragments (measuring approximately $3 \mathrm{~mm}$ ) from CNS from the cow and its fetus were fixed in $2 \%$ glutaraldehyde in phosphate buffer. Later, they were post-fixed in $1 \%$ osmium tetroxide, dehydrated in increasing concentrations of ethanol and embedded in Epon. The ultra-thin sections were contrasted with uranyl acetate and lead citrate and examined under a transmission electron microscope.

\section{Lectin-histochemical technique}

Fragments of central nervous system (CNS) from the two caprine fetuses were prepared and studied under lectin-histochemistry. Lectins used are shown in Table 1 . The slides were deparaffinized in xylene and hydrated in decreasing concentrations of alcohol. The inactivation of endogenous peroxidase was performed with $3 \%$ hydrogen peroxide for 30 minutes and with heat recovery using a solution of $10 \mathrm{mM}$ citrate buffer (pH 6.0) in a water bath $\left(100^{\circ} \mathrm{C}\right)$ for 15 minutes. For the reduction of specific binding (background), sections were treated with skim milk (Molico®) 5\% for 30 minutes. Subsequently, the lectins were applied at a dilution of $5 \mu \mathrm{g} / \mathrm{ml}$ in PBS (phosphate buffered saline) pH 7.4, except for the lectin Con-A, which was diluted at $1 \mu \mathrm{g} / \mathrm{ml}$. Then the slides were incubated in a moist chamber at $40^{\circ} \mathrm{C}$ for $12-14$ hours "overnight".

Table 1. Lectins used in histochemical study of poisoning by Sida carpinifolia

\begin{tabular}{lcl}
\hline \multicolumn{1}{c}{ Lectin } & Abbreviation & \multicolumn{1}{c}{ Carbohydrate specificity ${ }^{\mathrm{a}}$} \\
\hline Concanavalia ensiformis & Con-A & $\alpha$-D-Man; $\alpha$-D-Glc \\
Glycine max & SBA & $\alpha$-D-GalNac; $\beta$-D-GalNac; $\alpha$ e $\beta$-Gal \\
Dolichos biflorus & DBA & $\alpha$-D-GalNac \\
Ulex europaeus-1 & UEA-1 & $\alpha$-L-Fuc \\
Triticum vulgaris & WGA & $\beta$-D-GlcNac, NeuNac \\
Succinyl-WGA & sWGA & $(\beta-(1-4)-D-G l c N a c)^{2}$ \\
Arachis hypogaea & PNA & $\beta$-D-Gal(1-3) GalNac \\
Ricinus communis-1 & RCA-1 & $\beta$-D-Gal $>\alpha$-D-Gal \\
${ }^{\text {a }}$ Goldstein I.J. \& Hayes C.E. (1978). Fuc $=$ fucose, Gal = galactose, GalNac \\
$=$ N-acetil-galactosamina, Glc = glicose, GlcNac = N-acetil-glicosamina, \\
\multicolumn{2}{l}{ Man = manose, NeuNac = N-acetil-neuraminic acid. }
\end{tabular}

Thereafter, each slide with their respective lectins was individually washed with distilled water and PBS. Streptavidin was then applied (DAKO LSAB 2 kit, DAKO Corp., Carpinteria, CA) for 20 minutes in a moist chamber. The revelation of the sections was performed with the chromogen diaminobenzidine (DAB) (DAKO) for 10 minutes and then counterstained with Harris hematoxylin for 30 seconds and mounted with Entellan (Merck, Darmstadt, Germany Sigma Chemical Co., Saint Louis, USA) and observed under optical microscope.

\section{RESULTS}

During the experimental period, goats showed only mild clinical signs such as slow moving and dullness, but no 
change in feces consistency was noticed. After the end of daily dosages, goats started to increase body weight, at a rate of $119-110 \mathrm{~g} /$ day. The sole significant gross findings at post mortem examination of the goats were edema and increased size of lymph nodes, but without significant histopathological changes. The cow presented a clinical picture of incoordination, generalized tremors, staggering and frequent falls when it was stimulated to move. While the cow had no gross changes at necropsy, histopathological changes included vacuolation of Purkinje neurons of cerebellum, pancreatic acinar cells, and thyroid follicular cells. Transmission electron microscopy of sections from thalamus of the cow revealed vacuoles containing fine granular material surrounded by a membrane.

The main histopathological changes observed in the two caprine fetuses were moderate distention and vacuolation of the epithelium of renal tubules and slight disappearance of Nissl substance in neurons of the CNS. There were no pathological changes in the control goat and her fetuses. The main histological findings in the bovine fetus were marked vacuolation of the epithelial cells of renal tubules and moderate vacuolation of the follicular cells of the thyroid (Fig.1). There were no pathological changes in the control

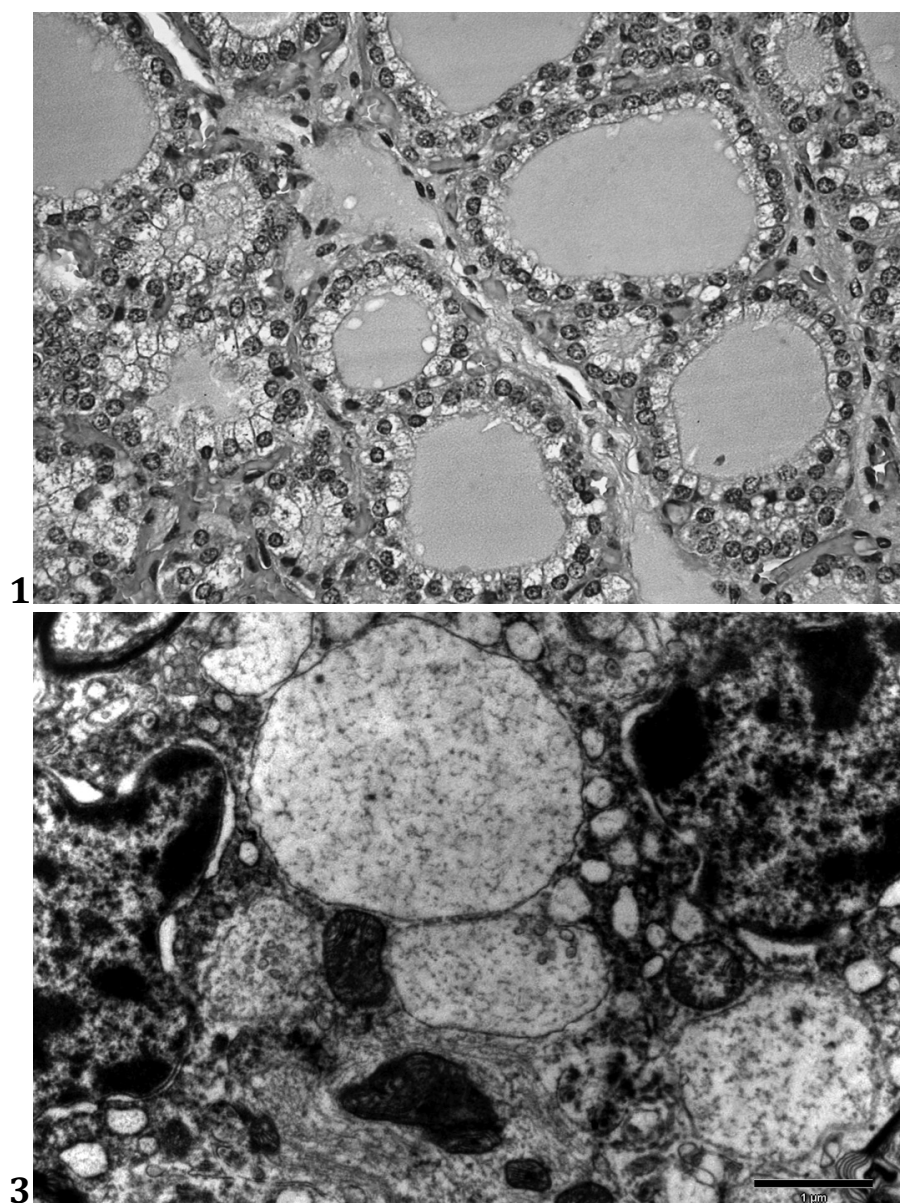

Fig.1. Bovine fetus. Thyroid. Moderate vacuolation of follicular cells. Hematoxylin and Eosin, obj.40x.

Fig.3. Bovine fetus. Cerebellum. Small vacuoles containing finely granular material membrane delimited. Transmission electron microscopy. Bar: $1 \mu \mathrm{m}$. of the bovine fetus (Fig.2). The cerebellum of the bovine fetus had mild vacuolation of the Purkinje neurons, which under transmission electron microscopy revealed small vacuoles containing finely granular material membrane-delimited (Fig.3). Lectin-histochemistry of CNS sections from caprine fetuses showed mild staining with the sWGA (Fig.4), WGA and Con-A.

\section{DISCUSSION AND CONCLUSION}

Poisoning by Sida carpinifolia in these animals was consistent with clinical, histopathological, ultrastructural, and lectin-histochemical findings from previous reports. It has been demonstrated that livestock poisoned by plants containing swainsonine such as Oxytropis spp. and Astragalus spp. (locoweeds) have also been affected by congenital defects, birth of weak offspring, and abortions (James 1972, Hartley \& James 1975), which have been associated with transplacental toxicosis (James 1971) interfering with embryonic and fetal development (James et al. 1992).

The consumption by pregnant goats of Sida carpinifolia has been associated with abortions and stillbirths; however, after stopping consumption of $S$. carpinifolia, goats conceive and due normal kids (Driemeier et al. 2000, Colodel et al.

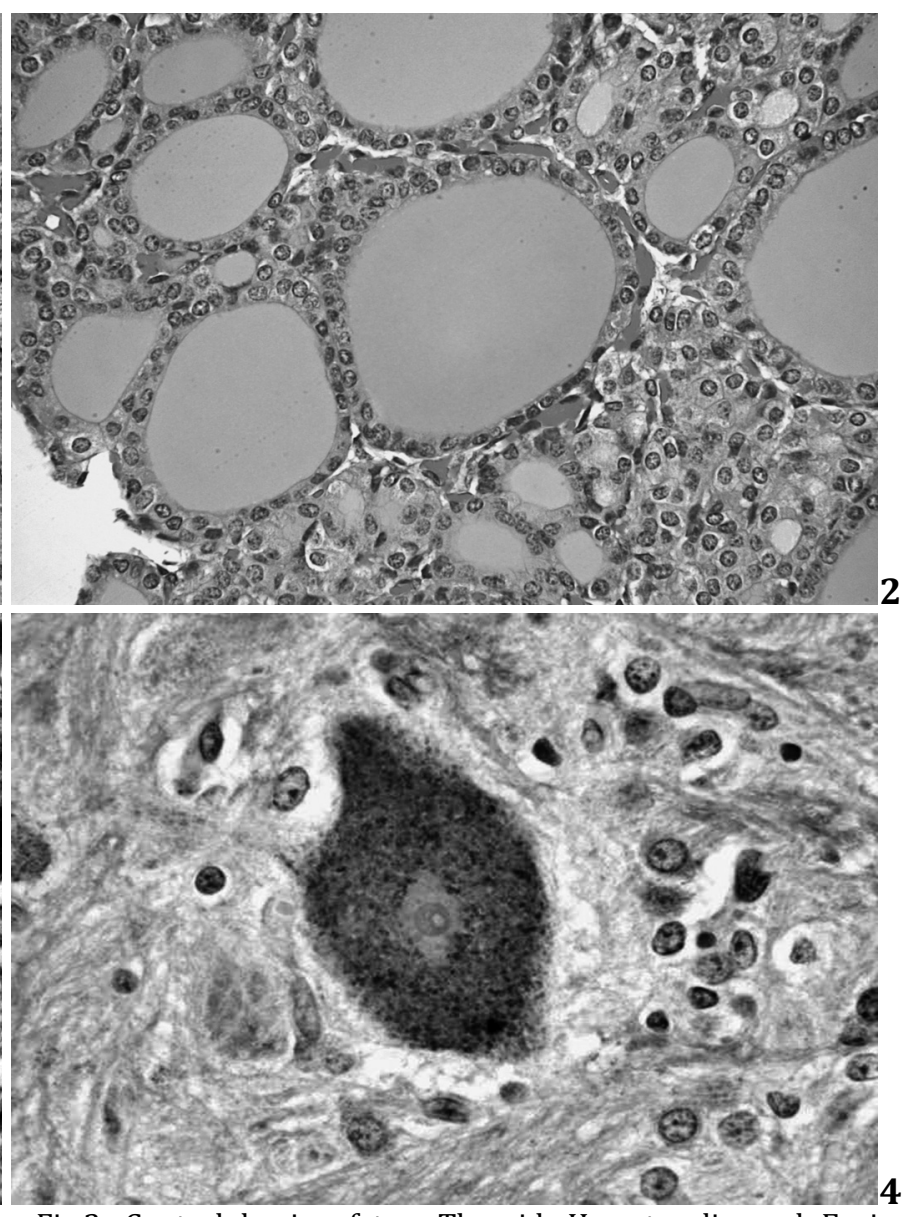

Fig.2. Control bovine fetus. Thyroid. Hematoxylin and Eosin, obj.40x.

Fig.4. Caprine fetus 1. CNS. Marking for Succinyl WGA (sWGA). Lectin-histochemical, obj.40x. 
2002a). The aforementioned factors suggest that $S$. carpinifolia consumption may affect fertility in open goats, as well as may cause pregnancy losses. In addition, sheep experimentally poisoned with $S$. carpinifolia experienced complete clinical recovery after ceasing consumption for a few days (Seitz et al. 2005a). Similar findings were observed here.

The caprine and bovine fetuses from this study had not their gestation interrupted; however, if animals had consumed the plant for longer periods, it may be said that abortion or other disorder could have affected them. These fetuses exhibited histopathological lesions mainly located in epithelial cells of proximal convoluted renal tubules and follicular cells of thyroid; therefore, similar findings as observed in sheep experimentally poisoned by Astragalus lentiginosus (James 1971, James 1972, Hartley \& James 1975). If such lesions would be capable of producing abortion, stillbirth, or other reproductive disorder in these fetuses is unknown and remain to be proved.

Poisoning by $S$. carpinifolia has been characterized as an $\alpha$-mannosidase (Driemeier et al. 2000), in which accumulation of oligosaccharides containing $\alpha$-mannose and $\beta$-N-acetyl-glucosamine (GlcNAc) has been demonstrated (Beaudet 1983). Sections from fetuses of this showed affinity by the lectins sWGA, WGA, and Con-A. Lectins WGA and sWGA characteristically mark GlcNAc residues (Monsingny et al. 1980), and lectin Con-A binds specifically to $\alpha$-mannose (Goldstein \& Hayes 1978). Pattern seen on lectin-histochemistry here is similar to that observed previously in S. carpinifolia poisoned sheep, deer and cattle (Seitz et al. 2005b, Pedroso et al. 2009, Pedroso et al. 2010, 2011).

Findings reported here confirm that Sida carpinifolia must be included in the list of poisonous plants linked to reproduction disorders in Brazilian livestock such as Aspidosperma pyrifolium, Ateleia glazioviana, Tetrapterys spp., Stryphnodendron spp., and Mimosa tenuiflora (Riet-Correa 2007, Lima \& Soto-Blanco 2010).

Acknowledgements.- This study was funded by Conselho Nacional de Desenvolvimento Científico e Tecnológico (CNPq), Brazil. Authors are grateful to professor Cláudio Estêvão Farias da Cruz (UFRGS) for reviewing this manuscript.

\section{REFERENCES}

Antoniassi N.A.B., Ferreira E.V., Santos C.E.P., Arruda L.P., Campos J.L.E., Nakazato L. \& Colodel E.M. 2007. Intoxicação espontânea por Ipomoea carnea subsp. fistulosa (Convolvulaceae) em bovinos no Pantanal Matogrossense. Pesq. Vet. Bras. 27:415-418.

Armién A.G., Tokarnia C.H., Peixoto P.V. \& Frese K. 2007. Spontaneous and experimental glycoprotein storage disease of goats induced by Ipomoea carnea subsp. fistulosa (Convolvulaceae). Vet. Pathol. 44:170-184.

Barbosa R.C., Riet-Correa F., Medeiros R.M.T., Lima E.F., Barros S.S., Gimeno E.J., Molyneux R.J. \& Gardner D.R. 2006. Intoxication by Ipomoea sericophylla and Ipomoea riedelli in goats in the state of Paraíba, Northeastern Brazil. Toxicon. 47:371-379.

Barbosa R.C., Riet-Correa F., Lima E.F., Medeiros R.M.T., Guedes K.M.R., Gardner D.R., Molyneux R.J. \& Melo L.E.H. 2007. Experimental swainsonine poisoning in goats ingesting Ipomoea sericophylla and Ipomoea riedelli (Convolvulaceae). Pesq. Vet. Bras. 27:409-414.

Bedin M., Colodel E.M., Viapiana M., Matte U., Driemeier D. \& Giugliani R. 2010. Alpha-manosidase activity in goats fed Sida carpinifolia. Exp. Toxicol. Pathol. 62:191-195.
Beaudet A.L. 1983. Disorders of glycoprotein degradation: mannosidosis, fucosidosis, sialisidosis ad aspartylglycosaminuria, p.788-802. In: Stanbury J.B., Wyngaarden J.B., Fredrickson D.A.S., Goldstein J.L. \& Brown M.S. (Eds), The Metabolic Basis of Inherited Diseases. $5^{\text {th }}$ ed. McGraw-Hill, New York.

Colegate S.M., Dorling P.R. \& Huxtable CR. 1979. A spectroscopic investigation of swainsonine: an alfa-mannosidase inhibitor isolated from Swainsona canescens. Aust. J. Chem. 32:2257-2264.

Colodel E.M., Driemeier D., Loretti A.P., Gimeno E.J., Traverso S.D., Seitz A.L. \& Zlotowski P. 2002a. Aspectos clínicos e patológicos da intoxicação por Sida carpinifolia (Malvaceae) em caprinos no Rio Grande do Sul. Pesq. Vet. Bras. 22:51-57.

Colodel E.M., Gardner D.R., Zlotowski P. \& Driemeier D. 2002b. Identification of Swainsonine as a glycoside inhibitor responsible for Sida carpinifolia poisoning. Vet. Human Toxicol. 44:177-178.

Dantas A.F.M., Riet-Correa F., Gardner D.R., Medeiros R.M.T., Barros S.S., Anjos B.L. \& Lucena R.B. 2007. Swainsonine-induced lysosomal storage disease in goats caused by the ingestion of Turbina cordata in Northeastern Brazil. Toxicon. 49:111-116.

Driemeier D., Colodel E.M., Gimeno E.J. \& Barros S.S. 2000. Lysosomal storage disease caused by Sida carpinifolia in goats. Vet. Pathol. 37:153-159.

Goldstein I.J. \& Hayes C.E. 1978. The lectins carbohydrate binding proteins of plants and animals. Adv. Carbohydr. Chem. Biochem. 35:127-340.

Hartley W.J. \& James L.F. 1975. Fetal and maternal lesions in pregnant ewes ingesting Locoweed (Astragalus lentiginosus). Am. J. Vet. Res. 36:825-826

James L.F. 1971. Lesions in neonatal lambs resulting from maternal ingestion of Locoweed. Cornell Vet. 61:667-670.

James L.F. 1972. Effect of Locoweed on fetal development: preliminary study in sheep. Am. J. Vet. Res. 33:835-840.

James L.F., Panter K.E., Nielsen D.B. \& Molyneux R.J. 1992. The effect of natural toxins on reproduction in livestock. J. Anim. Sci. 70:1573-1579.

Jolly R.D. \& Walkley S.U., 1997. Lysosomal storage disease of animals: an essay in comparative pathology. Vet. Pathol. 34:527-548.

Kissmann K.G. \& Groth D.G. 2000. Plantas Infestantes e Nocivas. Tomo III. BASF S.A., São Bernardo do Campo, SP. 722p.

Lima M.C.J. \& Soto-Blanco B. 2010. Poisoning in goats by Aspidosderma pyrifolium Mart.: biological and cytotoxic effects. Toxicon. 55:2-3:320-324.

Lorenzi H. 2008. Plantas Daninhas do Brasil: terrestres, aquáticas, parasitas e tóxicas. $4^{\underline{a}}$ ed. Instituto Plantarum de Estudos da Flora Ltda, Nova Odessa, SP. 640p.

Monsigny M., Roche A.C., Sene C., Marget-Domma R. \& Delmotte F. 1980. Sugar-lectin interations: how dos wheat-germ agglutinin bind sialoglycoconjugates? Eur. J. Biochem. 104:147.

Pedroso P.M.O., Von Hohendorf R., Oliveira L.G.S., Schmitz M., Cruz C.E.F. \& Driemeier D. 2009. Sida carpinifolia (Malvaceae) poisoning in fallow deer (Dama dama). J. Zoo Wildl. Med. 40:583-585.

Pedroso P.M.O., Oliveira LG.S., Cruz C.E.F., Soares M.P., Barreto L.R.B. \& Driemeier D. 2010. Doença do armazenamento lisossomal induzida pelo consumo de Sida carpinifolia em bovinos no Rio Grande do Sul. Pesq. Vet. Bras. 30:833-838.

Pedroso P.M.O., Gouvêa F.H.F., Antoniassi N.A.B., Gava A. \& Driemeier D. 2011. Lectin-histochemistry in the diagnosis of lysosomal storage disease induced by consumption of Sida carpinifolia in cattle in Brazil. Braz. J. Vet. Pathol. 4:1-4.

Pfister J.A., Stegelmeier B.L., Gardner D.R. \& James L.F. 2003. Grazing of spotted locoweed (Astragalus lentiginosus) by cattle and horses in Arizona. J. Anim. Sci. 81:2285-2293.

Riet-Correa F. 2007. Plantas tóxicas e micotoxinas que afetam a reprodução em ruminantes e equinos no Brasil. Biológico, São Paulo, 69:63-68.

Seitz A.L., Colodel E.M., Barros S.S. \& Driemeier D. 2005a. Intoxicação experimental por Sida carpinifolia (Malvaceae) em ovinos. Pesq. Vet. Bras. 25:15-20.

Seitz A.L., Colodel E.M., Schmitz M., Gimeno E.J. \& Driemeier D. 2005b. Use de lectin histochemistry to diagnose Sida carpinifolia (Malvaceae) poisoning in sheep. Vet. Rec. 156:386-388.

Stegelmeier B.L., Molyneux R.J., Elbein A.D. \& James L.F. 1995. The lesions of locoweed (Astragalus mollissimus), swainsonine, and castanospermine in rats. Vet. Pathol. 32:289-298. 